DOI: https://doi.org/10.31073/mivg202102-293

Available at (PDF): http://mivg.iwpim.com.ua/index.php/mivg/article/view/293

UDC 631.421.1:633.62:628.381.1

\title{
RECYCLING BIOSOLIDS TO IMPROVE MARGINAL LANDS FOR BIOENERGY FEEDSTOCK PRODUCTION IN UKRAINE
}

\author{
N.O. Didenko1, Ph.D., Y.B. Mosiichuk', Ph.D., M.D. Zosymchuk ${ }^{3}$, Ph.D., M.M. Kharytonov ${ }^{4}$, \\ D.A. Sci, M.G. Babenko ${ }^{5}$, Ph.D., B.O. Mazurenko ${ }^{6}$, Ph.D., S.O. Lavrenko ${ }^{7}$, Ph.D., M.A. Rahman ${ }^{8}$, \\ Ph.D., K.R. Islam ${ }^{9}$, Ph.D. \\ ${ }^{1}$ Institute of Water Problems and Land Reclamation of NAAS of Ukraine; \\ https://orcid.org/0000-0002-0654-4231; e-mail: 9449308nd@gmail.com; \\ ${ }^{2}$ Institute of Water Problems and Land Reclamation of NAAS of Ukraine; \\ https://orcid.org/0000-0002-9754-6522; e-mail: y.mosiichuk@gmail.com; \\ ${ }^{3}$ Institute of Water Problems and Land Reclamation of NAAS of Ukraine; \\ https://orcid.org/0000-0002-7162-8300; e-mail: zosimchykm@gmail.com; \\ ${ }^{4}$ Dnipro State Agrarian and Economic University, Ukraine; \\ https://orcid.org/0000-0002-4650-5819; e-mail: kharytonov.m.m@dsau.dp.ua; \\ ${ }^{5}$ Dnipro State Agrarian and Economic University, Ukraine; \\ https://orcid.org/0000-0002-0920-3846; e-mail:mg.babenko@gmail.com; \\ ${ }^{6}$ National University of Life and Environmental Sciences of Ukraine; \\ https://orcid.org/0000-0002-4177-9909; e-mail: mazurenko.bohdan@nubip.edu.ua; \\ ${ }^{7}$ Kherson State Agrarian and Economic University, Ukraine; \\ https://orcid.org/0000-0003-3491-1438; e-mail: lavrenko.sr@gmail.com; \\ ${ }^{8}$ The Ohio State University South Centers, Piketon, Ohio, U.S.; \\ https://orcid.org/0000-0002-5215-3506; e-mail: rahman.220@osu.edu; \\ ${ }^{9}$ The Ohio State University South Centers, Piketon, Ohio, U.S.; \\ https://orcid.org/0000-0002-2244-0395; e-mail: islam.27@osu.edu;
}

Abstract. Energy independence is one of the national priorities facing Ukraine today. Plant-based feedstocks have the potential to diversify Ukraine's energy independence by decreasing dependence on petroleum-based energy, reducing greenhouse gas emissions, expanding renewable fuel industries and creating job opportunities. However, biofeedstock needs to be competitive on availability, performance, and price to produce, market, and produce fuels. We hypothesize that domestically produced feedstocks from sweet sorghum, using proactive recycling of nutrient-rich biosolids on vast areas of degraded and marginal lands, could be a win-win energy independence strategy in Ukraine. Our goal is to create for generating a steady-state source of biofeedstock and disseminate science-based knowledge and training to the clientele. Specific objectives are to: (1) establish research studies to evaluate growth and feedstock productivity, nutrient removal, and feedstock characteristics of sweet sorghum fertilized with biosolids on degraded and marginal lands in Rivne, Kherson, Dnipro, and Kyiv regions of Ukraine; and (2) determine the impact of biosolids and sweet sorghum on soil quality. Data collected on growth, feedstock production, feedstock characteristics, fuel potential, and high-value co-products (biochar) of sweet sorghum and soil quality will be evaluated by multivariate statistics. Input, output, and outreach data will be subject to techno-economic analyses to evaluate the economically viability, environmentally compatibility, and social acceptability of the project. Traditional and electronic outlet activities will be utilized to disseminate outcomes and outputs and to evaluate project impacts.

Key words: biofuels, professional development, soil quality, sweet sorghum, waste recycling

1. Introduction. Energy independence is one of the national priorities facing Ukraine (Velychko \& Tretiako, 2010; Kharytonov, 2019a) as Ukraine is the net importers of geo-thermal energy. In recent years, the Government of Ukrainian has prioritized to derive $25 \%$ of its total energy generation from alternate sources by 2035 .

Ukraine is the $2^{\text {nd }}$ largest country in Europe with $70 \%$ of its land with various degrees of degradation is under conventional agriculture. While using best farmlands to grow energy crops is not a logical choice, and the question is: how can the economic benefits of growing crops for energy and bio-based products in degraded lands be balanced by the environmental concerns? The prospect of using existing prime land for harvesting corn, wheat, and soybean for ethanol, biodiesel, or bioenergy feedstock production is highly debated. So, while agronomic crops 
represent a significant biofuel source, it can also cause environmental degradation with increased agroecosystem disservices.

Energy crops that are already widely grown, or being developed, include corn (Zea mays, L.), soybeans (Glycine max), sunflower, switchgrass, big bluestem, Eastern Gamma grass, Sudansorghum, sweet sorghum (Sorghum bicolor (L.) Moench species), energy beet, sugarcane, Miscanthus (Miscanthus giganteus), Arundo, Guayule, Eucalyptus, and hybrid willow and poplar (Lavrenko et al., 2007; Tilman et al., 2011; Dweikat et al., 2012; Soudani et al., 2017; Islam, 2020).

Among them, sweet sorghum is one of the dedicated multipurpose bioenergy crops, which can be grown on degraded and marginal soils to withstand diverse conditions due to its versatile adaptability, high biomass yield potential $\left(\mathrm{C}_{4}\right.$ pathway), high sugar contents, greater waterand nutrient-use efficiency, and low maintenance life cycle when compared to other agronomic and bioenergy crops (Wortmann et al. 2010). Growing sweet sorghum on marginal lands can be a promising eco-friendly win-win situation to supplement Ukraine's growing energy needs due to its unique mechanism of moisture regulation, sorghum is highly tolerant to drought and salinity stresses, insects, pests. and diseases (Reddy et al., 2007; Dalla Marta et al., 2014; Rakhmetov et al., 2018; Kharytonov et al., 2019ab) (Fig. 1).

Biosolids are nutrient-rich organic byproducts of municipal water treatment facilities that can be used to rejuvenate marginal land productivity for growing sweet sorghum (Yucel et al., 2015; Soudani et al., 2017; Kharytonov et al., 2019 abc, Islam et al., 2020). It is expected that proactive recycling of biosolids will sustain energy feedstock production on marginal lands by providing labile organic matter, increasing availability of essential plant nutrients, and sustain plant growth. Moreover, the impact of biosolids amendments under relatively less disturbed soil
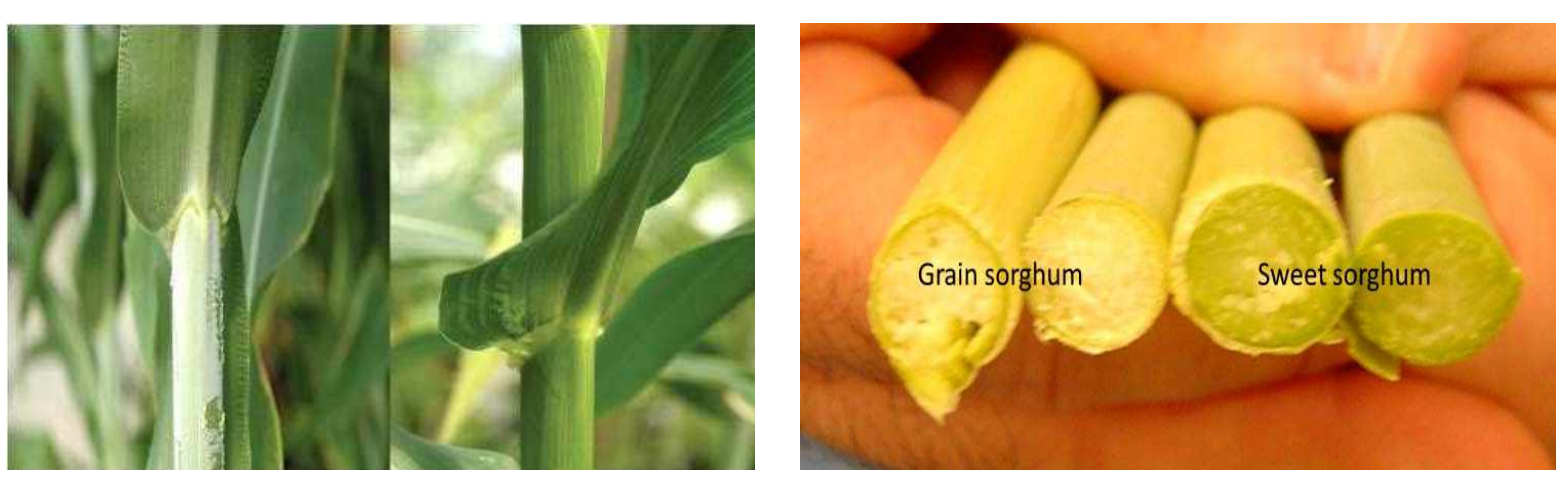

Fig. 1. Sweet sorghum growth and cane production (Dweikat et al., 2012)

environment is expected to support microbial diversity and efficiency (anabolism), increase $\mathrm{C}: \mathrm{N}$ stoichiometry to decrease greenhouse gas emissions, increase soil carbon sequestration, and improve soil quality. However, very limited studies were conducted to evaluate the effects of municipal biosolids on the growth, yield, and feedstock characteristics of sweet sorghum when grown on marginal lands in Ukraine (Kharytonov et al., 2019).

The goal of the research is to create possibilities for generating a steady-state source of biofeedstock to support energy independence. Specific objectives are to: (1) establish research studies to evaluate growth and feedstock productivity, nutrient removal, and feedstock characteristics of sweet sorghum fertilized with biosolids on degraded and marginal lands in the Rivne, Kherson, Dnipro, and Kyiv regions of Ukraine; (2) determine the impact of biosolids and sweet sorghum cropping on soil quality; (3) provide research training to Ukrainian scientists for professional development and institutional capacity building; and (4) develop outreach educational materials.

2. Materials and methods. The study area. Field experiments will be conducted simultaneously at Rivne (northwest), Kyiv (north), Dnipro (southeast), and Kherson (south) regions of Ukraine under contrasting soil and climatic conditions (Fig. 2).

Experimental design. A randomized complete block (RCB) design in a 4 (biosolids rates) $\mathrm{x} 2$ (sweet sorghum varieties) splitplot experiment with four replications will be established at four different locations, as described above (Fig. 2). Biosolids rates, as the main plot, will be 0 (control), 10, 20, and 40 kiloliters (KL), equivalent to $0,24,48$ and $96 \mathrm{~kg}$ $\mathrm{N} ; 0,10,20$ and $40 \mathrm{~kg} \mathrm{P}$; and 0, 8, 17, and $34 \mathrm{~kg}$ $\mathrm{K}$ per ha, respectively, compared with a standard chemical NPK fertilization treatment. Sweet sorghum variety (U.S vs. Ukrainian) will be the 


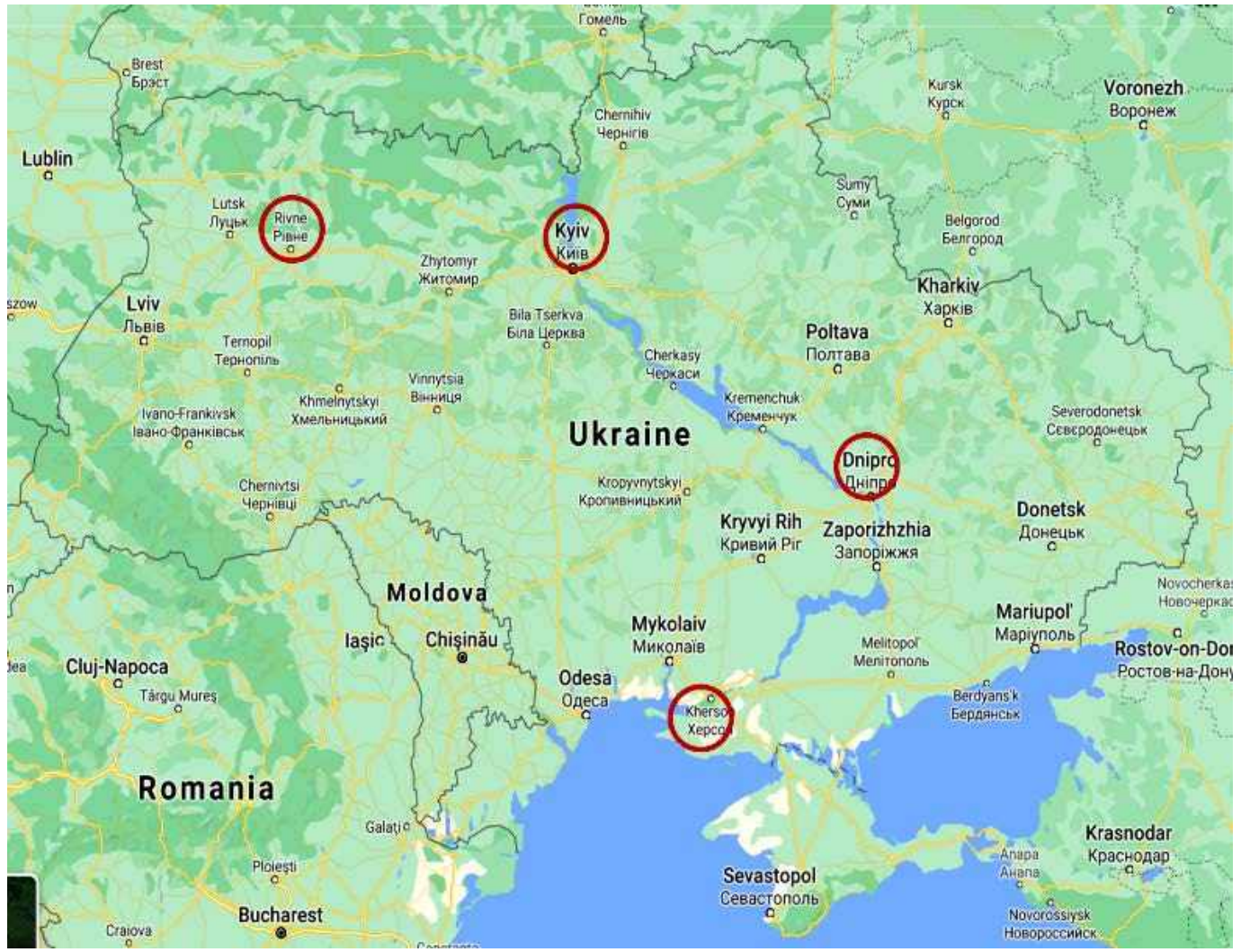

Fig. 2. Experimental location (red)

(https://www.google.com/maps/place/Ukraine)

sub-plot. Each replicated plot will be 35-m long $x$ 15-m long with a 2-m buffer between plots.

Based on our preliminary studies (Kharytonov et al., 2019abc), we have selected Zubr (Ukrainian variety) and Mohawk (U.S. RAELIN company and University of Nebraska-Lincoln) varieties of sweet sorghum due to their versatility, site and climatic adaptability in Ukraine, higher water and nutrient-use efficiency, biomass production, and cane sugar concentration. The rates of biosolids amendments were calculated based on currently available data on Ukrainian biosolids nutrient concentration (Mosiichuk, 2017). Biosolids will be collected from domestic wastewater treatment plants at respective sites.

Field operation and cultural practices. In early autumn 2021, all the experimental sites will be prepared to lay-out the experimental plots. Within a week, biosolids as the main plot will be surface applied at the proposed rates at each site. After 48-h, biosolids amended will be chisel plowed to incorporate the biosolids into the soil followed by planting of winter rye as a cover crop. In the early spring (late March), rye will be rolled over or terminated by applying herbicides followed by no-till (NT) planting of sweet sorghum in mid-April, as per cultural practices. Sweet sorghum at Rivne and Kyiv will be grown under rainfed conditions, in contrast to those grown under deficit irrigation in Dnipro and Kherson sites.

Growth, biomass productivity, and feedstock quality. Sweet sorghum growth, physiological and metabolic processes (photosynthesis, transpiration, respiration, and stomatal conductance) will be determined and recorded, using a portable photosynthesis system at different growth stages. Cane yield and total biomass production will be recorded at harvest. Based on on-site weather data, the reference evapotranspiration (ET) and crop coefficients $(\mathrm{Kc})$ will be determined for irrigation scheduling and to calculate for water-use efficiency of sweet sorghum. Crop residues on the surface and in the soil (roots) after annual harvesting, will be sampled from 2-m x 2-m blocks to calculate for annual flow of organic residue (carbon) in ecosystems. Using all the data, several drought stress tolerant and adaptivity indices of sweet sorghum will be calculated.

Sweet sorghum cane will be mechanically squeezed to extract juice for measuring sugar content, brix, conservative sugar yield (CSY), and theoretical ethanol yields (TEY). The TEY will be calculated as sugar yield multiplied by 0.58-L ethanol per kg of CSY (Rutto et al., 2013). While a modified Anthrone-reactive method will 
be used to determine for total glucose equivalent sugar content (Islam \& Weil, 2000), the brix will be determined by reflectometry. The CSY (ton/ ha) will be calculated (Wortmann et al., 2010) as:

$$
\mathrm{CSY}=(\mathrm{FSY}-\mathrm{DSY}) \cdot \text { brix } \cdot 0.75
$$

where FSY and DSY are fresh and dry cane yields, respectively.

Biomass samples will be oven-dried at $55 \pm 2{ }^{\circ} \mathrm{C}$, ground, and analyzed for total $\mathrm{C}$ and $\mathrm{N}$ contents by CNS analyzer, and for total $\mathrm{P}$, $\mathrm{K}, \mathrm{Ca}, \mathrm{Mg}, \mathrm{S}$, and micronutrients ( $\mathrm{Fe}, \mathrm{Mn}, \mathrm{Cu}$, and $\mathrm{Zn}$ ) using Inductively Coupled Plasma Emission Spectrometry. Moreover, bioprocessing characteristics of feedstock will be analyzed for different lignocelluloses, caloric values, and silica ( $\mathrm{Si}$ ) and heavy metals $(\mathrm{Al}, \mathrm{Pb}, \mathrm{Cd}$, $\mathrm{Cr}$, and $\mathrm{Ni}$ ) contents. Lignocelluloses will be determined by hydrolysis and HPLC analysis for monosaccharides. The ash content of biomass will be determined by the loss of ignition method. The EPA-3051 method will be used for heavy metals content of feedstock by ICPE Spectrometry. Moreover, a thermogravimetric analysis of biomass will be carried out to obtain information on thermal stability to estimate for differential mass loss and heating effects of biomass.

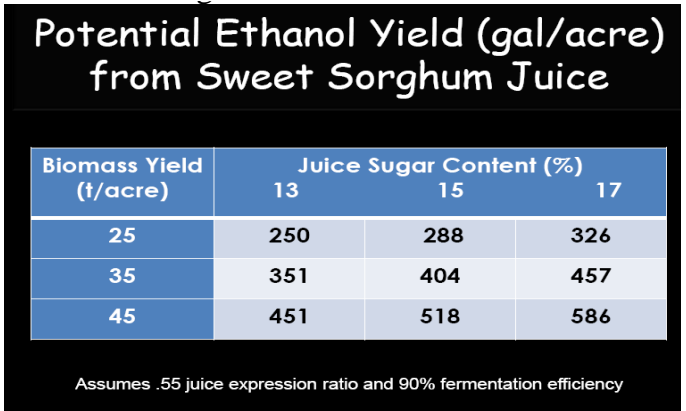

Fig. 3. Potential bioenergy (ethanol) yield of sweet sorghum (Dweikat et al., 2014)

Soil sampling and analysis. To evaluate the effects of sweet sorghum cropping and biosolids amendments on soil quality, composite soils (as baseline) will be sampled from all sites in early autumn prior to laying out the experiments and at the end of the experiment. The soil will be collected from $0-45 \mathrm{~cm}$ depth with a $15 \mathrm{~cm}$ interval from each replicated plot following the systematic sampling technique. While a portion of the field-moist soil will be processed to analyze for key biological properties, another portion of the soil will be air-dried and processed to analyze for key chemical and physical properties using standard methods.

Soil biological properties. Soil total microbial biomass will be determined by using the rapid microwaved soil irradiation and extraction method (Islam \& Weil, 1998). Basal respiration (BR), as an indicator of soil biological activity, will be determined by following the in vitro static incubation method (Islam \& Weil, 2000). Several metabolic quotients ( $\mathrm{qR}$ and $\mathrm{qCO}_{2}$ ) as measures of ecosystem stress or recovery on soil will be calculated (Anderson \& Domsch, 1990; Islam \& Weil, 2000).

Soil chemical properties. Total soil organic $\mathrm{C}$ (SOC) and total $\mathrm{N}$ (TN) contents will be determined using the automated dry combustion CNS analyzer. Soil active $\mathrm{C}$ (AC) and N (AN), as composite indicators of soil quality and $\mathrm{N}$ availability, will be determined using a modified $\mathrm{KMnO}_{4}$ oxidation method (Islam et al., 2021). Soil macro- (P, Ca, Mg, K, and S) and micronutrients (Fe, Mn, $\mathrm{Cu}, \mathrm{Zn}, \mathrm{B}, \mathrm{Mo}$ ), and heavy metals ( $\mathrm{Al}, \mathrm{Pb}, \mathrm{Co}, \mathrm{Cr}$, and $\mathrm{Ni}$ ) will be analyzed by Melich-3 extraction and inductively coupled plasma emission spectrometry. Soil $\mathrm{pH}$ and electrical conductivity will also be measured using electrode methods.

Soil physical properties. Soil bulk density and penetration resistance will be determined using the standard core method and digital penetrometer. Soil moisture-holding capacity will be measured using thermo-gravimetric methods. Soil aggregate stability will be evaluated by determining macro- and microaggregate stability and aggregation and persistence indices (Kempers \& Rosenau, 1986; Jahangir et al., 2020; Islam et al., 2021).

Quantification of soil quality. Both inductive (key soil properties) and deductive (biomass, sugar yield) additive approaches will be used to calculate for soil quality index (Amoakwah et al., 2021; Islam et al., 2021). Using the standardized scoring functions that state «higher, lower, or mean values $\left(S Q_{\text {Index }}=\left[\sum\left(X_{0} X_{\max }^{-1}\right)+\left(X_{0} X_{\text {mean }}{ }^{-1}\right)+\right.\right.$ $\left.\left.+\left\{1-\left(X_{0} X_{\max }^{-1}\right)\right\}\right] n^{-1}\right)$ are better indicators of soil quality", a half of the data will be normalized in a scale $(>0$ to $\leq 100)$ relative to the maximum value of that indicator in the dataset to remove variability (Fig. 4). The normalized scores will be evaluated by principal components analysis (PCA) to select key soil quality indicators as a minimum dataset (MDS) to calculate a generalized soil quality index $(>0$ to $\leq 100)$, with 100 being excellent in quality and 0 being extremely poor quality.

Based on the PCA analysis to select MDS (first set), the other half of the data will be normalized, summed, and calculated for soil quality index (second set). Finally, soil quality index calculated based on the first and second sets will be correlated and subjected to the analysis 


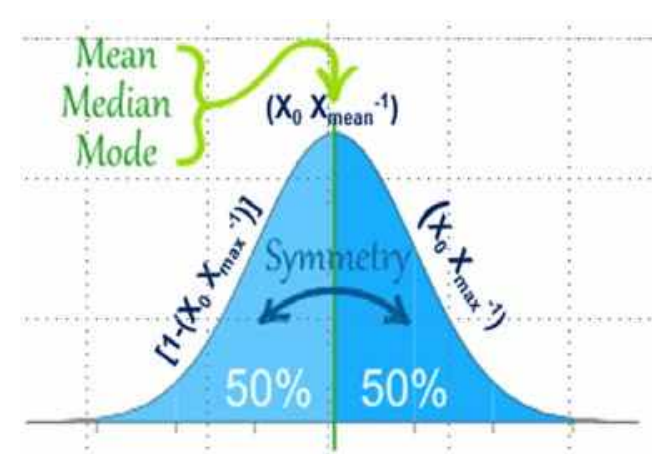

Fig. 4. Concept of soil quality modeling

of variance to control redundancy and validate the quantification on changes in soil quality (Amoakwah et al., 2021).

Modeling of soil carbon sequestration. The stocks of SOC and TN data in different pools at each depth and within the soil profile will be calculated by multiplying their concentration with the concurrently measured bulk density (variable mass). However, to account for extra soil mass from using concurrently measured bulk density among and/or between soils from different treatments, an "equivalent soil depth" will be used to convert SOC and TN concentration into massper-unit area (Aziz et al., 2013). The stocks of SOC and TN in different pools, based of calculation of antecedent bulk density or equivalent soil depth, will be regressed over time to calculate for SOC sequestration and $\mathrm{TN}$ accumulation rates and $\mathrm{C}$ : $\mathrm{N}$ stoichiometry in soil organic matter.

Statistical analysis and techno-economical assessment. Multivariate procedures will be used for data analysis and interpretation of results. These procedures will provide the most up-todate capabilities for ANOVA by allowing the calculation of $\mathrm{F}$ and $\mathrm{P}$ values to separate simple and interactive effects of predictor variables on dependent variables using the least square difference (LSD) test at $p \leq 0.05$, unless otherwise mentioned. The PCA will be performed to identify core soil and crop properties as minimum datasets to account for soil quality variations in response independent variables. Regression and correlation analyses will be performed to calculate for SOC sequestration using polynomial, hyperbola, exponential, and power models.
We will also log all inputs, operating costs, feedstock yields, biofuel potential, nutrient removal, heavy metal impact, greenhouse gas emissions, and SOC sequestration. Using all these inputs and outputs, we will perform a techno-economic analysis to evaluate the prospects of raising sweet sorghum energy plantations on biosolids amended marginal lands in Ukraine. The methodology outlined in published papers will be used as a guide for techno-economic analysis (Perrin et al., 2008).

Conclusions. Municipal biosolids are a nutrient-rich organic byproduct of water treatment facilities, also can be used as a potentially viable source of biochemical amendment to rejuvenate the soil quality of marginal lands. Municipalities all over Ukraine have an abundance of biosolids, so the appeal of using them as an amendment to improve the soil quality is quite logical because the approach, as a natural system, will facilitate an environmentally compatible disposal system for efficient nutrient recycling to support biofeedstock production. While energy crops are not grown for food, forage, or feed, applying municipal biosolids to rejuvenate marginal lands for producing biofeedstock poses no danger to human or animal health. By adopting traditional and electronic outreach approaches, we will document project outcomes and outputs, which will include: increased knowledge on sweet sorghum biofeedstock production on marginal lands; increased economic activity associated with the recycling of biosolids, biofeedstock production, processing and marketing, and creation of green jobs to improve the rural economy; change in public policy for recycling biosolids to rejuvenate marginal land; and utilization of $25 \%$ of marginal lands in Ukraine for biofeedstock production by 2050 .

Acknowledgement. U.S. National Science Foundation (NSF) via Civilian Research and Development Foundation (CRDF) Global and the Ministry of Education and Science of Ukraine (MES) have funded our project research as part of the U.S.-Ukrainian Alternative Energy Research Competition.

\section{References}

1. Velichko, S.A., \& Tretyakov, O.S. (2010). Alternatyvna enerhetyka Ukrainy [Alternative energy of Ukraine]. Kharkiv : Osnova.

2. Kharytonov, M.M., Martynova, N.V., Tokar, A.V., Rula, I.V., Babenko, M.G., \& Bagorka, M.O. (2019). Sweet sorghum biomass quantitative and qualitative characteristic depending on hybrid and type of soil. INMATEH - Agricultural Engineering Journal, 59 (3), 189-196. http://www.inmateh.eu/ INMATEH_3_2019/59-21-Kharytonov\%20M.pdf 
3. Mrynsky, I.M., \& Lavrenko S.O. (2007). Bioenergetic efficiency of elements of technology of cultivation of hybrid seed (F1) of sunflower "Visit". Taurian Scientific Bulletin: Collection of scientific papers, 52, 98-102.

4. Tilman, D., Balzer, C., Hill, J., \& Befort, B.L. (2011). Global food demand and the sustainable intensification of agriculture. $P N A S, 108$ (50), 20260-20264. https://doi.org/10.1073/pnas.1116437108

5. Dweikat, I., Weil, C., Moose, S., Kochian, L., Mosier, N., Ileleji, K., Brown, P., Peer, W., Murphy, A., Taheripour, F., McCann, M., \& Carpita, N. (2012). Envisioning the transition to a nextgeneration biofuels industry in the US Midwest. Biofuels, Bioproducts and Biorefining, 6, 376-386. https://doi.org/10.1002/bbb.1342

6. Soudani, L., Woloszyn, M., Fabbri, A., Morel, J., \& Grillet, A., (2017). Energy evaluation of rammed earth walls using long term in-situ measurements. Solar Energy, 141, 70-80. https://doi.org/10.1016/j.solener.2016.11.002

7. Islam, K.R. (2020) Growing Miscanthus for biofuels on marginal land amended with sewage sludge and flue gas desulfurized gypsum. JBRA, 1 .

8. Wortmann, C.S., Liska, A., Ferguson, R.B., Lyon, D.J., Klein, R. N., \& Dweikat, I.M. (2010). Dryland performance of sweet sorghum and grain crops for biofuel in Nebraska. Agronomy \& Horticulture - Faculty Publications, 387. https://digitalcommons.unl.edu/agronomyfacpub/387

9. Reddy, M.V., Yu, T., Sow, C.H., Shen, Z.X., Lim, C.T., Subba Rao, G.V., \& Chowdari, B.V.R. (2007). $\alpha-\mathrm{Fe}_{2} \mathrm{O}_{3}$ Nanoflakes as an Anode Material for Li-Ion Batteries. Advanced Functional Materials, 17(15), 2792-2799. https://doi.org/10.1002/adfm.200601186

10. Marta, A.D., Mancini, M., Orlando, F., Natali, F., Capecchi, L., \& Orlandini, S. (2014). Sweet sorghum for bioethanol production: Crop responses to different water stress levels. Biomass and Bioenergy, 64, 211-219. https://doi.org/10.1016/j.biombioe.2014.03.033

11. Rakhmetov, D.B., Vergun, O.M., Blum, Ya.B., Rakhmetova, S.O., \& Fishchenko, V.V. (2018). Biochemical composition of plant raw material of sweet sorghum (Sorghum saccharatum (L.) Moench) genotypes. Introduktsiia roslyn, 3, 93-90. http://nbuv.gov.ua/UJRN/IR 2018311

12. Kharytonov, M., Martynova, N., Babenko, M., Rula, I., Sytnyk, S., Bagorka, M, \& Gavryushenko, O. (2019). Bioenergetic assesment of sweet sorghum grown on reclaimed lands. Acta technica corviniensis - Bulletin of Engineering, 12(3), 89-92. http://acta.fih.upt.ro/pdf/2019-3/ ACTA-2019-3-18.pdf

13. Yucel, I., Onen, A., Yilmaz, K.K., \& Gochis, D.J. (2015). Calibration and evaluation of a flood forecasting system: Utility of numerical weather prediction model, data assimilation and satellitebased rainfall. Journal of Hydrology, 523, 49-66. https://doi.org/10.1016/j.jhydrol.2015.01.042

14. Shedekar, V.S., King, K.W., Fausey, N.R., Islam, K.R., Soboyejo, A.B.O., Kalcic, M., \& Brown, L.C. (2020). Exploring the effectiveness of drainage water management on water budgets and nitrate loss using three evaluation approaches. Agricultural Water Management. Agric. Water Manage. 243, 106501.

15. Kharytonov, M., Martynova, N., Babenko, M., Rula, I., Gumentyk, M., Bagorka, \& Pashova, V. (2019). The production of biofuel feedstock on reclaimed land based on sweet sorghum biomass. AgricultForest, 65(4), 233-240. DOI:10.17707/AgricultForest.65.4.21

16. Mosiichuk, Y.B., \& Walery, M. (2017). Purification of domestic wastewater in closed water systems in agribusiness biofilters floating loading. Environmental Engineering - Through a young eye, 36, 99-109. Retrieved from https://ismo.pb.edu.pl/wp-content/uploads/2017/05/VOLUME-36ENVIRONMENTAL-ENGINEERING-SYSTEMS.pdf\#page=99

17. Rutto, L., Xu, Y., Brandt, M., Ren, S., \& Kering, M. (2013). Juice, Ethanol, and Grain Yield Potential of Five Sweet Sorghum (Sorghum bicolor [L.] Moench) Cultivars. Journal of Sustainable Bioenergy Systems, 3, 113-118. doi:10.4236/jsbs.2013.32016

18. Islam, K., \& Weil, R. (2000). Soil quality indicator properties in mid-Atlantic soils as influenced by conservation management. Journal of Soil and Water Conservation, 55(1), 69-78.

19. Islam, K., \& Weil, R. (1998). Microwave irradiation of soil for routine measurement of microbial biomass carbon. Biol Fertil Soils, 27, 408-416. https://doi.org/10.1007/s003740050451

20. Anderson, T.H., \& Domsch, K.H. (1990). Application of eco-physiological quotients $\left(q \mathrm{CO}_{2}\right.$ and $\left.q \mathrm{D}\right)$ on microbial biomasses from soils of different cropping histories. Soil Biology \& Biochemistry, 22, 251-255.

21. Dweikat, I., Damasceno, C.M.B., Schaffert, R. (2014). Mining genetic diversity of sorgum as a Bioenergy feedstock. Plants and BioEnergy. Vol. 4, p. 81-106. DOI: 10.1007/978-1-4614-9329-7_6

22. Islam, K.R., Roth, G., Rahman, M.A., Didenko, N.O., \& Reeder, R.C. (2021). Cover crop complements flue gas desulfurized gypsum to improve no-till soil quality. Communications in Soil Science and Plant Analysis, 52(9), 926-947. https://doi.org/10.1080/00103624.2021.1872594 
23. Kemper, W.D., \& Rosenau, R.C. (1986). Aggregate stability and size distribution. American Society of Agronomy-Soil Science Society of America, 677 South Segoe Road, Madison, WI 53711, USA. Methods of Soil Analysis. Part 1. Physical and Mineralogical Methods-Agronomy Monograph no. 9 ( $2^{\text {nd }}$ Edition $), 425-442$.

24. Jahangir, M.H., \& Cheraghi, R. (2020). Economic and environmental assessment of solarwind-biomass hybrid renewable energy system supplying rural settlement load. Sustainable Energy Technologies and Assessments, 42, 100895. https://doi.org/10.1016/j.seta.2020.100895

25. Amoakwah, E., Arthur, E., \& Frimpong, K.A. (2020). Soil organic carbon storage and quality are impacted by corn cob biochar application on a tropical sandy loam. J Soils Sediments, 20, 1960-1969. https://doi.org/10.1007/s11368-019-02547-5

26. Aziz, R.F., \& Hafez, S.M. (2013). Applying lean thinking in construction and performance improvement. Alexandria Engineering Journal, 52 (4), 679-695. https://doi.org/10.1016/j.aej.2013.04.008

27. Perrin, R., Vogel, K., Schmer, M., \& Mitchell, R. (2008). Farm-Scale Production Cost of Switchgrass for Biomass. BioEnergy Research, 1, 91-97. https://doi.org/10.1007/s12155-008-9005-y

Н.О. Діденко, Я.Б. Мосійчук, М.Д. Зосимчук, М.М. Харитонов, М.Г. Бабенко, Б.О. Мазуренко, С.О. Лавренко, А.М. Рахман, К.Р. Іслам Використання біосолідів для покращення якості маргінальних земель та виробництва біоенергетичної сировини в Україні

Анотація. Енергетична незалежність є одним із національних пріоритетів, які сьогодні стоять перед Україною. Рослинна сировина має потенціал для диверсифікаиії енергетичної незалежності Украӥни шляхом зменшення залежності від нафтової енергії, скорочення викидів парникових газів, розширення виробництва відновлюваних джерел палива та створення робочих місиь. Однак біосировина повинна бути конкурентоспроможною за доступністю, характеристиками та вартістю для виготовлення, продажу та виробниитва палива. Припускаємо, що сировина, отримана із солодкого сорго, може бути використана в біоенергетиці для подальшого формування стратегії енергетичної незалежності в Україні. І особливо актуально, коли для вирошування будуть задіяні площі деградованих і маргінальних земель з попереднім внесенням біосолідів (осаду стічних вод), багатих пожсивними речовинами. Мета роботи полягає у розвитку взаємопродуктивної та технічно-інноваційної дослідницької співпраиі між Університетом штату Огайо та кількома науководослідними установами в Україні для створення стабільного джерела біосировини та поширення науково обгрунтованих знань і навчання зацікавлених сторін. Основними цілями є: (1) провести наукові дослідження для оиінки приросту та продуктивності, виносу поживних речовин та характеристик иукрового сорго, удобреного осадом стічних вод на деградованих та маргінальних землях у Рівненській, Херсонській, Дніпропетровській та Київській областях Украӥни; та (2) оиінити вплив біотвердих речовин та посівів иукрового сорго на якість трунту. Дані щодо росту, виробниитва, якісних характеристик отриманої сировини, паливного потенціалу та високоцінних побічних продуктів (біовугілля) солодкого сорго та якості трунту, будуть проаналізовані за допомогою багатовимірної статистики. Вхідні, вихідні та інформаційні дані підлягатимуть техніко-економічному аналізу для оцінки економічної дочільності, екологічної сумісності та соиіальної прийнятності проєкту. Традиційні та електронні засоби поширення інформації будуть використовуватися для розповсюдження результатів та висновків, а також для оцінки впливу проєкту.

Ключові слова: біопаливо, підвищення кваліфікації, якість трунту, солодке сорго, утилізація відходів

Н.А. Диденко, Я.Б. Мосейчук, М.Д. Зосимчук, М.М. Харитонов, М.Г. Бабенко, Б.А. Мазуренко, С.А. Лавренко, А.М. Рахман, К.Р. Ислам Использование биосолидов для улучшения качества маргинальных земель и производства биоэнергетического сырья в Украине

Аннотация. Энергетическая независимость - одна из национальных приоритетов, стоящиих сегодня перед Украиной. Растительное сырье имеет потенциал для диверсификации энергетической независимости Украины за счет уменьшения зависимости от энергии на основе нефти, сокрашения выбросов парниковых газов, расширения производства возобновляемого топлива и создания рабочих мест. Однако биотопливо должсно быть конкурентоспособным по доступности, характеристикам и цуене для производства, сбыта и производства топлива. Предполагаем, что сырье, полученное из сладкого сорго, может использоваться в биоэнергетике для дальнейшего формирования стратегии энергетической независимости в Украине. И особенно актуально, когда для вырашивания будут задействованы площуади деградированных и маргинальных земель с предварительным. Цель работы состоит в развитии взаимопродуктивного и технически инновационного исследовательского сотрудничества между Университетом штата Огайо и несколькими научно-исследовательскими учреждениями в Украине для создания стабильного источника биосырья 
и распространения научно обоснованных знаний и обучения заинтересованных сторон. Основные задачи проекта заключаются в следующем: (1) проведение научных исследований для оценки прироста и производительности, выноса питательных вещзеств и характеристик сахарного сорго, удобренного осадком сточных вод на деградированных и маргинальных землях в Ровенской, Херсонской, Днепропетровской и Киевской областях Украины; и (2) определить влияние твердых биологических вещцеств и сладкого сорго на качество почвы. Собранные данные о росте производства, качественных характеристик полученного сырья, топливном потенциале и иеенных побочных продуктах (биоуголь) сладкого сорго и качестве почвы будут проанализированы с помощью многомерной статистики. Входящие, исходящие и информационные данные подлежат технико-экономическому анализированию для оценки экономической изелесообразности, экологической совместимости и сочииальной приемлемости проекта. Традиционные и электронные источники информаџии будут использоваться для распространения результатов и выводов, а также для оценки воздействия проекта.

Ключевые слова: биотопливо, повышение квалификации, качество почвы, сладкое сорго, утилизация отходов. 